RAD Conference Proceedings, vol. 3, pp. 63-67, 2018

ISSN 2466-4626 (online) | DOI: 10.21175/RadProc.2018.13

www.rad-proceedings.org

\title{
CBRN DEFENCE: ORGANIZATION, RESOURCES AND TASKS OF SERBIAN ARMED FORCES
}

\author{
Stevan Musicki', Dejan Vasovic ${ }^{2 *}$, Srdjan Markovic3 \\ ${ }^{1}$ University of Defence, Secondary Military School, Belgrade, Serbia \\ ${ }^{2}$ University of Nis, Faculty of Occupational Safety in Nis, Nis, Serbia \\ 3Ministry of Defence, Department for General Logistics, Belgrade, Serbia
}

\begin{abstract}
The concept of CBRN (chemical, biological, radiological, nuclear) defence is a highly complex phenomenon and a scientific discipline within both the social and technical-technological sciences. CBRN defence has multiple meanings. In the most general sense, it refers to absence/elimination or minimization of threats, i.e. pressures that can threaten people, property, and the environment. Effective and efficient CBRN defence activities can be seen from the perspective of civil structures or armed forces. In this sense, the organizational structure of the armed forces of any country represents a dynamic system which, within the wider community, operates and exists under specific conditions and circumstances. Starting from its basic purposes, the regular armed forces of any state do not have unknowns regarding the rules and their core roles. However, the complex structure and the interdependence of different organizational structures within the country and within the armed forces have an impact on the implementation of measures in the field of CBRN defence and management of risk both in war and peacetime. The aim of this paper is to present the structural organization, resources and tasks of the Serbian armed forces (SAF) within the field of CBRN defence.
\end{abstract}

Key words: CBRN defence, armed forces, organization

\section{BACKGROUND - TASKS, FORCES, AND ASSETS OF THE SERBIAN ARMED FORCES UNITS FOR PROVIDING ASSISTANCE TO THE POPULATION DURING CBRN ACCIDENTS}

In narrow sense, the CBRN defense represents measures and procedures for the protection of the population, soldiers, the living environment and its ecosystem components, techniques, and other material resources from the adverse effects of chemical, biological, and nuclear (atomic) and contaminants. The CBRN defense is the part of the armed forces that is responsible for planning, preparing, organizing and directly executing security tasks against nuclear, chemical or biological hazards. In addition to reconnaissance, alerting and observation, the CBRN defense consists of a process of decontamination, dosimetry, evaluation, assessment and the elimination of the consequences of CBRN contamination. Nuclear, biological and chemical accidents and health threats to humans and the environment due to the contamination by radiological, biological and chemical contaminants pose constants risk to persons and property in Republic of Serbia [1].

Normative and legal regulation, the establishment of an efficient emergency safety and rescue system, as well as support from other structures of the government system and other state institutions pose a challenge, which needs to be taken into account when organizational and legislative reforms are being implemented [2]. The primary goal is to unify all activities directed toward protecting life, health, and property, to preserve the necessary living conditions, and to overcome situations involving fires, natural disasters, hazardous materials, and other hazards [3, 4].

Planning for the Serbian Armed Forces (SAF) deployment has to incorporate the military response to challenges, risks, and threats to security. The planning is conducted according to:

- the received missions and tasks;

- the possible scenarios of national security threats;

- the state of SAF;

- the plans for defence system development;

- guidelines and decisions [5].

SAF devise deployment plans, crisis prevention plans, and crisis response plans. SAF deployment plan is an integral part of the general Defence Plan of Serbia. Crisis prevention plans are devised in order to respond to potential crises. They are based on constructed scenarios regarding crisis outbreaks and developments and they are devised on all command levels. They can serve as the foundation for crisis response plans. Crisis response plans are devised as a response to an ongoing crisis. If SAF should participate in international operations, special plans need to be

*djnvasovic@gmail.com 
devised, pursuant to the decision by the Serbian National Assembly. Plans of engaging SAF in helping the civilian authorities to fight security threats are enacted within crisis prevention planning and according to each specific situation. The CBRN service battalion, as the largest unit of this SAF service, is supposed to handle the majority of chemical accident remediation tasks. If requested by the authorised bodies and approved by the Ministry of Defence, a portion of the CBRN personnel would be sent to the chemical accident zone to assist the state bodies that coordinate all agencies and personnel in the afflicted zone [6]. However, due to the particular nature of the emergency (high concentrations of hazardous materials, short response window, highly specific fires), it is difficult to allocate the adequate amount of CBRN manpower under given conditions $[7,8]$.

\section{TASKS OF THE SERBIAN ARMED ForCES UNITS FOR PROVIDING ASSISTANCE TO THE POPULATION DURING CBRN ACCIDENTS}

SAF units, institutions, and army reserves can be called upon to provide assistance to the civilian population during $\mathrm{CBRN}$ accidents. In peacetime, they would generally perform the following tasks:

- determining CBRN hazard type and level;

- controlling the level of radioactive and chemical contamination;

- protecting people, animals, and property against contamination; and

- mitigate the effects of contamination.

The specific tasks performed by a unit during a CBRN accident depend on the type of that unit [9].

$C B R N$ units - by utilising formation means and additional assets, they perform the following tasks: control of radioactive and chemical contamination; mitigation of nuclear and chemical accident effects (radiological and chemical surveillance, rescue, fire suppression, decontamination, etc.). The most prominent is the platoon for protection against nuclear and chemical accidents with the $246^{\text {th }} \mathrm{CBRN}$ battalion of the Serbian Army, which is called upon for CBRN protection across the entire territory of Serbia, per request by the security authority and order of the commanding officer [10].

Airborne units control radioactive contamination from the air, especially in inaccessible areas; perform evacuation and transport; and neutralise the effects of CBRN accidents using specialised aircraft (helicopters with buckets).

Engineer corps units use the basic assets (engineering machines, amphibians, etc.) to control water courses and mitigate the negative effects - clear the debris, re-establish communication channels, and evacuate and rescue people and property.

Armour units carry out surveillance of terrains with high levels of radioactivity and evacuate the areas.

Infantry units participate in the organization of control and safety services and rescue and evacuate people and property.
Military police units secure the accident area and perform other tasks within their jurisdiction.

River flotilla units conduct CBRN surveillance and decontamination and rescue and evacuate people and property on inland navigable water courses.

Quartermaster units and institutions provide food and water supplies and co-control food and water contamination and protection and decontamination of buildings and other property during CBRN accidents.

Traffic control units and bodies ensure that the traffic flows uninterruptedly in case of accident and are directly involved in transport to the afflicted areas and evacuation of people and property.

Medical units control the contamination using gamma-spectrometric, toxicological, and chemical analyses of samples and provide immediate care of the contaminated, the poisoned, and the sick during an accident. In addition to the existing organization for accident intervention, they also form professional crews and teams.

If civilian government forces are unable to fully respond to an accident (which is the case in the modelled CBRN accident), temporary SAF forces are formed, following a formal request and an evaluation of the number of personnel required, in order to help the afflicted populace and mitigate the effects of the accident. The modelled armed forces represent one of the possible ways of organizing the temporary forces in their assistance to the civilian authorities to mitigate the effects of the CBRN accident.

The modelled armed forces are enlisted together with the civilian forces, but all the forces receive their orders from the city emergency response centre, which incorporates the SAF liaison officer [11].

\section{SAF DEPLOYMENT IN CBRN DECONTAMINATION}

CBRN decontamination involves a set of measures and activities to remove and neutralize radiological and chemical contaminants released during accidents, which reduces the hazard in contaminated environments or surfaces to acceptable contamination levels. The end goal of decontamination is the complete removal of radioactive contaminants, neutralization of chemical contaminants, and minimization of the overall contamination.

During peacetime CBRN accidents, the following entities may be subject to decontamination: people, animals, technical assets, clothing and equipment, soil, and buildings. Decontamination can be either full or partial.

Partial decontamination involves the removal of contaminants from specific parts of the body (face, neck, arms, etc.). It is only temporary, whereas full decontamination is the desired outcome.

Full decontamination of people is performed by the CBRN units in designated facilities (decontamination stations). Decontamination of the injured and the sick is performed by the medical units in designated facilities. Injured and sick animals are decontaminated in veterinary facilities. Soil and building decontamination is performed by CBRN units, as well 
as other armed forces, e.g. the engineer corps, when a specific layer of the soil needs to be removed, or tank trucks from the logistics units for soil washing, etc. [11]

It must be emphasized that SAF CBRN units are situated only in the Kruševac garrison, which implies that the utilization of these units at longer distances is more difficult and inexpedient. The assets of the 246th CBRN battalion of the Serbian Army are classified into the following groups: protection, decontamination, dosimetry and radiometry of ionizing radiation, detection and identification of toxic chemicals, teaching tools for imitating the effects of nuclear, chemical and fire-fighting weapons and non-lethal chemicals for temporary disabling. Some of the mentioned assets within the SAF equipment also have quality certificates of relevant international institutions that are competent to issue them, thus achieving compatibility with similar resources of the modern armies of the world.

In order to make the most out of the CBRN units for an integrated response to a CBRN accident, it is necessary to use the appropriate methodology for decision making and for choosing the units to be utilized in a given situation [12]. For their decision making during combat, NATO experts often adhere to the D3 methodology - Detect, Decide, Destroy. The focus is on the superior technology which is used first to detect the target, then to make a decision on the optimal use, and finally to efficiently destroy the selected target. SAF use an asymmetric strategy based on the O3 methodology: Discover (Serb. otkrij - O1), Decide (Serb. odluči - O2), and Disable/Enable (Serb. o(ne)mogući - O3), where the term Destroy is replaced by the terms Disable/Enable. Due to SAF limitations, primarily material, technical, and financial, it has to resort to the strategy of disabling the enemy from completing their mission in a specific area by using weapons of mass destruction and during contamination caused by attacks on processing industry facilities, and enabling its own units to survive when performing different tasks in complex conditions [13].

If we consider the two said methodologies in terms of modelling the deployment of CBRN units in an integrated response to a CBRN accident, we can conclude that the $\mathrm{O}_{3}$ methodology is fully acceptable provided certain modifications, where an algorithm of activities can provide a complete picture of all the particularities of this complex process. Within the $\mathrm{O} 1$ stage, the main issue is the absence of a reliable software for proper collection and processing of CBRN hazard data, which would otherwise accelerate the making of an optimal decision. The $\mathrm{O} 2$ stage stresses the importance of full risk analysis, proper elaboration of the accident scenario, and the design of an adequate CBRN unit model. Due to the lack of simulation software for verifying the selected model, the issue could be resolved through the analysis of model efficiency in mitigating the effects of a CBRN accident according to predefined criteria. After a completed decision-making process, the CBRN service commanding officer opts for the optimal mode of engaging the forces for a CBRN accident. During the O3 stage, CBRN units are included in the integrated response to a CBRN accident together with other involved agencies and forces. Full coordination and prompt corrective action during mitigation are prerequisites for successful task completion.

Based on the CBRN unit selected to assist with the accident (e.g. CBRN accident security unit), the activities are undertaken as follows:

- $\quad$ CBRN units are deployed to the accident site and integrated with other forces that provide the integrated accident response (local selfgovernment forces, firefighters, medical units, etc.);

- the direction of contamination (outside the accident epicentre) is inspected; and

- $\quad$ the accident site is decontaminated (SAF units would be deployed for the decontamination of the portion of important access roads for the accident site, whereas the firefighters would be deployed for the decontamination of the accident epicentre, in accordance with their purview).

After arriving at the accident site, chemical surveillance forces would conduct surveillance of the site using a specialized surveillance vehicle and modern detection equipment. It should be noted that CBRN units primarily handle the issues of mitigating and eliminating the effects (after the use of improvised devices or after nuclear or chemical accidents), while they are much less frequently deployed for preventive action in these or similar situations. It is also very important to note that the $\mathrm{CBRN}$ units that are deployed for resolving a specific CBRN accident issue have to be supported by an adequate information system, so that they are able to constantly monitor the state of the environment in real time. SAF currently use two software packages: HeSPRO - Software for rapid assessment of a chemical incident (in all SAF units from battalion to division ranks) and NBC ANALYSIS (at the CBRN Staff Training Centre in Kruševac) [10].

\section{CONCLUSION}

The previous discussion shows the importance of operational coordination between civilian authorities, the armed forces, and other participants in CBRN accident mitigation. This requires designated persons to coordinate the activities by SAF and other participants, not only in the mitigation stage but also in the stages of risk assessment, planning, and designating manpower for potential accident response.

Likewise, successful preparation and deployment of forces in providing support to the civilian authorities in case of CBRN accidents requires continuous education of SAF members in coordination with other competent ministries within the field. The CBRN Staff Training Centre in Kruševac can play an active role in providing training to SAF members and other personnel that supports the civilian authorities during CBRN accidents. In addition to CBRN units, units able to perform evacuation and transport, as well as engineer corps, military police, infantry, logistics, and other units would also play an important part in providing support to civilian authorities during CBRN accidents. Current solutions by the state are such that each 
ministry plans its own tasks and forces in case of natural or technical and technological accidents, which is not particularly efficient. Deployment of SAF units as support to civilian authorities is limiting, since CBRN accidents require rapid response, proper equipment, and proper training for such tasks; several hours can pass from the moment the local self-government issues a request until SAF units are deployed. Considering the properties of hazardous materials, time is often a limiting factor of SAF unit deployment as it significantly influences their expediency.

A rapid, efficient, and reliable response to $\mathrm{CBRN}$ accidents requires well-equipped and well-trained forces, not only SAF but also other structures, beginning with manufacturing companies, through municipalities, cities, and districts to line ministries. In order to actively involve these forces in an integrated CBRN accident response, their joint mitigation training is required. The issue can be resolved by organizing joint trainings and exercises, work meetings, workshops, and scientific conferences pertaining to this field with active participation from all the aforementioned governing bodies in Serbia. SAF units and Ministry of Defence institutions can provide invaluable assistance in the matter, but only if they are fully trained and equipped to handle such tasks.

Acknowledgements: The presented research is a part of the projects "Development of new information and communication technologies, based on advances mathematical methods, with applications in medicine, telecommunications, power systems, protection of natural heritage and education" (III 44006) and "Research and development of energy efficient and environment friendly polygeneration systems based on renewable energy sources utilization" (III 42006), under the auspices of the Ministry of Education, Science and Technological Development, Republic of Serbia.

\section{REFERENCES}

1. Народна скупштина Републике Србије. (18.11.2011). Сл. гласник 86/2011 Национална стратегија заштите и спасавања у ванредним ситуацијама. (National Assembly of the Republic of Serbia. (Nov. 18, 2011). Official Gazette 86/2011 National strategy for protection and rescue procedures in emergency situations.)

Retrieved from: http://arhiva.mup.gov.rs/cms lat/sadr zaj.nsf/Nacionalna strategija zastite i s spasavanja u u vanrednim situacijama lat.pdf;

Retrieved on: Sep. 15, 2018

2. Народна скупштина Републике Србије. (01.04.2009). Стратегија националне безбедности Републике Србије. (Ministry of Defence of Republic of Serbia. (Apr. 1, 2009). National security strategy of the Republic of Serbia.)

Retrieved from: http://www.mod.gov.rs/multimedia/fil e/staticki_sadrzaj/dokumenta/strategije/Strategija\%2 onacionalne\%2obezbednosti\%20Republike\%20Srbije.p df;

Retrieved on: Sep. 30, 2018

3. Народна скупштина Републике Србије. (6.10.2012). Сл. гласник 93/2012 Закон о ванредним ситуацијама. (National Assembly of the Republic of
Serbia. (Oct. 6, 2012). Official Gazette 93/2012 Law on emergency situations.)

Retrieved from: http://prezentacije.mup.gov.rs/svs/ht ml/Zakon\%200\%20VS.pdf;

Retrieved on: Sep. 15, 2018

4. Народна скупштина Републике Србије. (25.9.2012). Закон о ванредним ситуацијама. (National Assembly of the Republic of Serbia. (Sep. 25, 2012) Law on emergency situations.)

Retrieved from: http://prezentacije.mup.gov.rs/svs/ht ml/Zakon\%200\%20VS.pdf;

Retrieved on: May 12, 2018

5. Народна скупштина Републике Србије. (28.09.2012). Закон о заштити од јонизујућег зрачења и нуклеарној сигурности. (National Assembly of the Republic of Serbia. (Sep. 28. 2012). Law on the ionizing radiation protection and nuclear safety.) Retrieved from: https://www.paragraf.rs/propisi/zakon o zastiti od jonizujucih zracenja i o nuklearnoj sigurnosti.html;

Retrieved on: Sep. 15, 2018

6. Народна скупштина Републике Србије. (10.05.2018). Закон о одбрани. (National Assembly of the Republic of Serbia. (May 10. 2018). Law on defense.)

Retrieved from: https://www.paragraf.rs/propisi/zakon o odbrani.html;

Retrieved on: Sep. 15, 2018

7. S. Mušicki, V. Nikolić, D. Vasović, "Resource protection - the Serbian Army experience," in Proc. VI International Symposium Engineering Management and Competitiveness (EMC 2016), Kotor, Montenegro, 2016, pp. $110-113$.

Retrieved from: http://www.tfzr.uns.ac.rs/emc/pastEM Cs.aspx;

Retrieved on: May 20, 2018

8. S. Mušicki, V. Nikolić, D. Vasović, "Safety, security, hazard and risk - a conceptual approach," in Proc. 7th DQM International Conference Life Cycle Engineering and Management (ICDQM-2016), Prijevor, Serbia, 2016, pp. $396-401$.

9. D. Vasović, J. Malenović Nikolić, G. Janacković, "A quick glance at disaster risk reduction from different perspectives," in Proc. Int. Conf. Life Cycle Engineering and Management (ICDQM-2016), Prijevor, Serbia, 2016, pp. $193-200$.

10. S. Mušicki, "Integrative model or resource protection improvement in MoD and SAF," Ph.D. dissertation, University of Defence, Military Academy, Belgrade, Serbia, 2016.

11. 246. батаљон АБХО, Војска Србије, Београд, Србија, 2018. (246 th CBRN battalion of the Serbian Army, Serbian Armed forces, Belgrade, Serbia, 2018.) Retrieved from: http://www.vs.rs/sr cyr/jedinice/vojs ka-srbije/kopnena-vojska/246-bataljon-abho; Retrieved on: Jun. 10, 2018

12. D. Indjic, "Possibility of the development of Serbian protection system of chemical accident," Mil. Tech. Cour., vol. 6o, no. 4, pp. 133 - 146, 2012.

Retrieved from: http://www.vtg.mod.gov.rs/archive/20 12/military-technical-courier-4-2012.pdf;

Retrieved on: Jun. 10, 2018

13. D. Baker et al., Guidebook to Decision-Making Methods. Department of Energy, Washington (DC), USA, 2002, pp. $2-5$.

Retrieved from: https://www.researchgate.net/publicat ion/255621095 Guidebook to DecisionMaking Methods;

Retrieved on: Jun. 10, 2018

14. Народна скупштина Републике Србије. (10.05.2018). Закон о Војсци Србије. (National Assembly of the Republic of Serbia. (May 10, 2018). Law on Serbian Armed Forces). 
S. Musicki et al., CBRN defence..., RAD Conf. Proc., vol. 3, 2018, 63-67

Retrieved from: https://www.paragraf.rs/propisi/zakon

Retrieved on: Sep. 15, 2018

_o vojsci srbije.html; 